Columbia Law School

Scholarship Archive

\title{
Principles of International Law and the Adoption of a Market- Based Mechanism for Greenhouse Gas Emissions from Shipping
}

\author{
Hillary Aidun \\ Columbia Law School, Sabin Center for Climate Change Law, hwa2108@columbia.edu \\ Daniel J. Metzger \\ Columbia Law School, Sabin Center for Climate Change Law, djm2244@columbia.edu \\ Michael B. Gerrard \\ Columbia Law School, michael.gerrard@law.columbia.edu
}

Follow this and additional works at: https://scholarship.law.columbia.edu/faculty_scholarship

Part of the Environmental Law Commons, and the International Law Commons

\section{Recommended Citation}

Hillary Aidun, Daniel J. Metzger \& Michael B. Gerrard, Principles of International Law and the Adoption of a Market-Based Mechanism for Greenhouse Gas Emissions from Shipping, (2021).

Available at: https://scholarship.law.columbia.edu/faculty_scholarship/2749 


\title{
ब田 \\ COLUMBIA LAW SCHOOL
}

SABIN CENTER FOR CLIMATE CHANGE LAW

\section{PRINCIPLES OF INTERNATIONAL LAW AND THE ADOPTION OF A MARKET- BASED MECHANISM FOR GREENHOUSE GAS EMISSIONS FROM SHIPPING}

\author{
By Hillary Aidun, Daniel J. Metzger and \\ Michael B. Gerrard
}

February 2021 


\section{(C) 2021 Sabin Center for Climate Change Law, Columbia Law School}

The Sabin Center for Climate Change Law develops legal techniques to fight climate change, trains law students and lawyers in their use, and provides the legal profession and the public with up-to-date resources on key topics in climate law and regulation. It works closely with the scientists at Columbia University's Earth Institute and with a wide range of governmental, nongovernmental and academic organizations.

Sabin Center for Climate Change Law

Columbia Law School

435 West $116^{\text {th }}$ Street

New York, NY 10027

Tel: +1 (212) 854-3287

Email: columbiaclimate@gmail.com

Web: http://www.ColumbiaClimateLaw.com

Twitter: @ColumbiaClimate

Blog: http://blogs.law.columbia.edu/climatechange

Disclaimer: This paper is the responsibility of The Sabin Center for Climate Change Law alone, and does not reflect the views of Columbia Law School or Columbia University. This paper is an academic study provided for informational purposes only and does not constitute legal advice. Transmission of the information is not intended to create, and the receipt does not constitute, an attorney-client relationship between sender and receiver. No party should act or rely on any information contained in this White Paper without first seeking the advice of an attorney.

This work was generously supported by the Environmental Defense Fund.

About the authors: Hillary Aidun and Daniel J. Metzger are Postdoctoral Research Scholars at Columbia Law School and Climate Law Fellows at the Sabin Center for Climate Change Law. Michael B. Gerrard is the Andrew Sabin Professor of Professional Practice at Columbia Law School and the Faculty Director of the Sabin Center for Climate Change Law. 


\section{EXECUTIVE SUMMARY}

Emissions from shipping are a significant driver of human-induced climate change. International action to date has not succeeded in setting those emissions on a sustainable trajectory. The International Maritime Organization has committed to implementing an effective, international approach to tackle international shipping's contribution to climate change.

This paper considers international law principles, exploring whether and how these principles may provide a basis for the IMO to address those contributions. The polluter pays principle, which counsels that whoever produces pollution should cover the costs their pollution imposes on others, is a doctrine of international law that offers strong support for the IMO to adopt a market-based mechanism to reduce greenhouse gas emissions. Other principles of international law provide that any market-based mechanism the IMO adopts should be consistent with international climate agreements, responsive to the different contributions that nations and companies have made to the climate problem, built on the best available science while resolving any uncertainties in favor of less risk to the environment, and respectful of universally-recognized rights - both individual and national - to equity, life, and fair treatment. 


\section{CONTENTS}

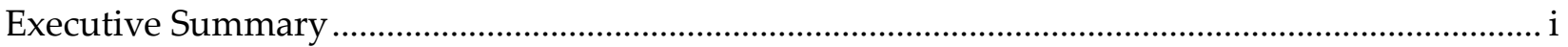

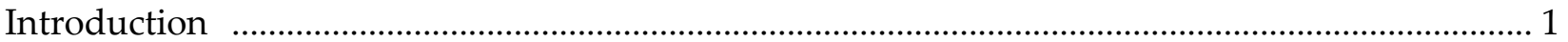

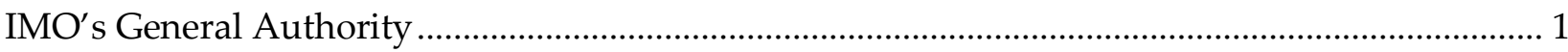

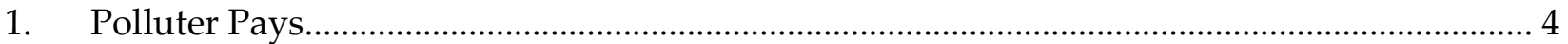

2. Paris Climate Agreement Principle of Highest Ambition ................................................... 8

3. Common But Differentiated Responsibilities.................................................................. 10

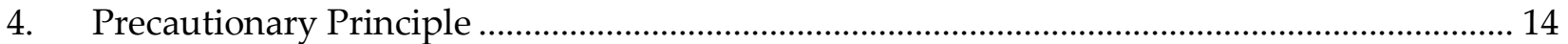

5. Transboundary Pollution and the No-Harm Principle .......................................................... 17

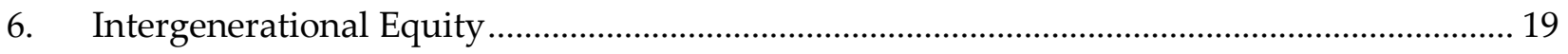

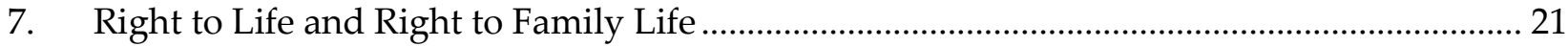

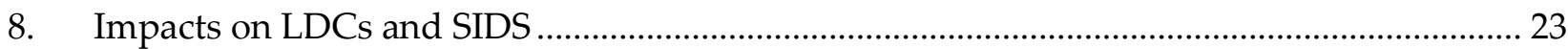

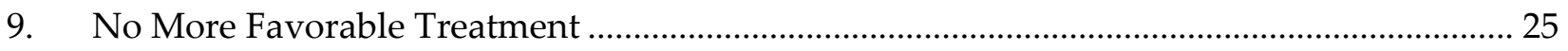

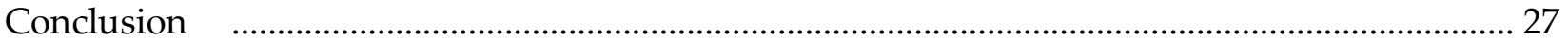




\section{INTRODUCTION}

Emissions from shipping comprise nearly 3\% of anthropogenic greenhouse gases (GHG) released worldwide and those emissions are currently on track to increase. ${ }^{1}$ But shipping was not explicitly addressed in the Paris Agreement, and the International Maritime Organization (IMO or the "Organization") has only taken early steps toward reducing international shipping's climate impact. The IMO has committed to adopting a comprehensive scheme to reduce international shipping emissions and raised the possibility of using a market-based mechanism (MBM). In order to clarify how the IMO can take further steps, this white paper discusses the principles of international law that establish and frame the Organization's authority to adopt an MBM to reduce GHG emissions. We consider nine of the most salient international law principles and explore whether and how these principles may provide a basis for the IMO to act, and to allocate some of the revenue generated by an MBM to small-island developing nations (SIDs) and other states particularly vulnerable to climate change impacts.

As discussed below, the IMO's authority to adopt an MBM on GHG emissions from shipping is grounded in a number of international law principles. The polluter pays principle offers the strongest support for imposing costs specifically on private entities such as shipping companies. Other principles provide a general basis for the IMO to rapidly decrease greenhouse gases from the shipping sector, and establish some parameters on what kind of measures the IMO can adopt.

\section{IMO'S GENERAL AUTHORITY}

The IMO's broad objectives give it authority to adopt a wide range of potential MBMs to reduced GHG emissions from ships. ${ }^{2}$ Article 1 of the IMO Convention describes the Organization's purpose as, among others, to "facilitate the general adoption of the highest practicable standards in matters concerning ... prevention and control of marine pollution from

${ }^{1}$ Marine Envtl. Prot. Comm. [MEPC], Fourth IMO GHG Study 2020 Annex 1, 3-4, MEPC Doc. 75/7/15 (July 20, 2020), https://docs.imo.org/Shared/Download.aspx?did=125134 [hereinafter Fourth IMO GHG Study].

${ }^{2}$ MBMs are the sole focus of this paper. But as further explained below, the IMO's authority is broad enough to cover a wide range of potential measures. 
ships." ${ }^{3}$ Article 2, which lays out the Organization's functions, places no substantive limitation on the types of measures it can undertake within a broad charge to "[p]rovide for the drafting of conventions, agreements, or other suitable instruments, and recommend these to Governments and to intergovernmental organizations, and convene such conferences as may be necessary." 4

The 1973/1978 International Convention for the Prevention of Pollution from Ships (MARPOL) governs pollution from the shipping sector. ${ }^{5}$ A subsidiary body of the IMO, the Marine Environment Protection Committee (MEPC), is broadly tasked with performing functions "for the prevention and control of marine pollution from ships, particularly with respect to the adoption and amendment of regulations or other provisions." 6 These include adopting and amending MARPOL's annexes, which address different types of pollution. ${ }^{7}$

In 2003 the IMO adopted a resolution setting out policies and priorities for reducing GHG emissions from ships. ${ }^{8}$ Among other items, the IMO directed the MEPC to prioritize its consideration of market-based solutions. ${ }^{9}$ In 2009 the MEPC considered a range of proposals, and while it did not adopt any, the committee "agreed by overwhelming majority that a market-based measured was needed as part of a comprehensive package of measures for the regulation [of] GHG emissions from international shipping." 10 A market-based measure is an instrument that:

${ }^{3}$ Convention on the International Maritime Consultative Organization, art. 1(a), March 6, 1948289 U.N.T.S. 3 [hereinafter, as subsequently amended by IMO resolutions, "IMO Convention].

${ }^{4} I d$. at art. 2(b).

${ }^{5}$ See PATRICIA Birnie et Al. InTERnATIONAL LAW AND the ENVIRONMENT 403 (3d ed. Oxford University Press 2009); see also International Convention for the Prevention of Pollution from Ships (as amended by Protocol of 1978), Nov. 2, 1973, 1340 U.N.T.S. 61 [hereinafter "MARPOL"]. ${ }^{6}$ IMO Convention, art. 38(a).

${ }^{7}$ BIRNIE ET AL., supra note 5.

8 Int'l Maritime Org. [IMO], A. 963 (23), IMO Policies and Practices Related to the Reduction of Greenhouse Gas Emissions from Ships (Mar. 4, 2004), https://wwwcdn.imo.org/localresources/en/ KnowledgeCentre/IndexofIMOResolutions/AssemblyDocuments/A.963(23).pdf.

${ }^{9}$ Id. II 1(d).

${ }^{10}$ Marine Envtl. Prot. Comm. [MEPC], Report of the Marine Environment Protection Committee on Its Fifty-Ninth Session II 4.106, MEPC Doc. 59/24 (July 27, 2009), https://docs.imo.org/Shared/ Download.aspx?did=56200. 
seek[s] to address the market failure of "environmental externalities" either by incorporating the external cost of production or consumption activities through taxes or charges on processes or products, or by creating property rights and facilitating the establishment of a proxy market for the use of environmental services. ${ }^{11}$

Since 2009, a wide range of measures have been proposed but so far not adopted. ${ }^{12}$

The sections that follow address principles of international law that bear on the IMO's authority to adopt an MBM to reduce GHGs. ${ }^{13}$ But first we say a word about the procedures necessary to adopt an MBM. The IMO's governing instruments provide for a vote on whether to adopt such a measure, ${ }^{14}$ but in practice the Organization typically seeks consensus before acting. ${ }^{15} \mathrm{It}$ is well recognized that searching for consensus can slow the IMO's decision making process, but the practice persists because of its perceived benefits-among others, increased acceptance of consensus-backed decisions and avoiding the divisiveness of a vote. ${ }^{16}$ But halting action until consensus is reached can result in deadlock, and there is precedent for the IMO to use its voting

${ }^{11}$ KOEN RADEMAEKERS ET AL., THE ROLE OF MARKET-BASED INSTRUMENTS IN ACHIEVING A RESOURCE EFFICIENT ECONOMY II 1.2.1 (2011), https://ec.europa.eu/environment/enveco/mbi/pdf/studies/role_marketbased.pdf (quoting ORGANIZATION FOR ECONOMIC CO-OPERATION AND DEVELOPMENT, BUSINESS AND THE ENVIRONMENT: POLICY INCENTIVES AND CORPORATE RESPONSES (2007)). 12 Market-Based Measures, IMO, https://www.imo.org/en/OurWork/Environment/Pages/MarketBased-Measures.aspx; see also Marine Envtl. Prot. Comm. [MEPC], Report of the Marine Environment Protection Committee on Its Seventy-Fifth Session II 7.28, MEPC Doc. 75/18 (Dec. 15, 2020), https://docs.imo.org/Shared/Download.aspx?did=126835 (approving draft amendments to MARPOL setting out technical and operational measures to reduce shipping's carbon intensity, but not market-based measures).

${ }^{13}$ See Aoife O'Leary \& Jennifer Brown, The Legal Bases for IMO Climate Measures (Sabin Center Working Paper, 2018), https://climate.law.columbia.edu/sites/default/files/content/docs/OLearyand-Brown-2018-06-IMO-Climate-Measures.pdf.

${ }^{14}$ See, e.g., IMO Convention art. 62.

15 See O'Leary \& Brown, supra note 13 at (noting that "in practice the IMO rarely calls for a vote and usually proceeds by consensus"); Harilaos N. Psaraftis \& Christos A. Kontovas, Influence and transparency at the IMO: the name of the game, 22 MARITIME ECON. \& LOGISTICS 151, 152 (2020) ("[A]s is common practice among UN bodies, the IMO operates on a consensus basis ....").

${ }^{16}$ See id. 
mechanisms where members cannot reach unanimity on a proposed measure. ${ }^{17}$ So the IMO could, even if some members object, proceed with an MBM that receives a majority vote but not unanimous support. ${ }^{18}$ Such a measure could be enforced through a combination of flag state and port state controls, as the IMO required for its recent measure limiting the sulfur content of fuels. ${ }^{19}$

\section{POLLUTER PAYS}

The polluter pays principle is a framework for addressing the problem of externalities. An externality is the impact of a transaction on third parties that do not participate in the transactionor, more generally, the impact of economic activity on society in general. Perhaps the paradigmatic example is pollution in a river caused by the normal operations of a factory. The question arises of who bears the burden of this pollution: the company that owns the factory, which receives the economic benefits; the consumers, who receive the benefit of consuming the company's products; downstream neighbors; or society in general. Without intervention, the burden will fall on downstream neighbors. The polluter pays principle teaches that the company should bear the cost of the pollution, which might then be passed on to consumers who drive demand for the company's product as the cost is internalized into the product's price. ${ }^{20}$

17 EUROPEAN PARLIAMENT, DireCTORATE-GENERAL FOR INTERNAL POLICIES, DECISION-MAKING PROCESSES OF ICAO AND IMO IN RESPECT OF ENVIRONMENTAL REGULATIONS at 14 (2016), https:/www.europarl.europa.eu/RegData/etudes/STUD/2016/595332/IPOL STU(2016)595332 EN. pdf ("A consequence of the search for unanimity is deadlocks in some areas, in particular the application of market-based mechanisms to reduce CO2 emissions from ships.") (citation omitted); see also Psaraftis \& Kontovas, supra note 15 at 152 ("[W]ith respect to EEDI/SEEMP, it was impossible to achieve consensus, and the measures were adopted by vote in spite of fierce resistance by a group of developing countries, including China, India, Brazil and Saudi Arabia."). ${ }^{18}$ For a detailed discussion of the specific processes by which the IMO could take this step, see O'Leary \& Brown, supra note 13 at 9-19.

19 See Marine Envtl. Prot. Comm. [MEPC] Resolution 321 (74), 2019 Guidelines for Port State Control Under MARPOL Annex VI Chapter 3 (May 17, 2019), https://wwwcdn.imo.org/localresources/en/ OurWork/Environment/Documents/MEPC.321\%2874\%29.pdf.

${ }^{20}$ See PierRe-MARIE Dupuy \& JORGE E. ViÑUALES, InTERNATIONAL ENVIRONMENTAL LAW 81-82 (2d ed. Cambridge University Press, 2018). 
An early recognition of polluter pays as a legal principle appears in a 1972 recommendation of the Organization for Economic Cooperation and Development (OECD) Council. ${ }^{21}$ The recommendation stated:

The principle to be used for allocating costs of pollution prevention and control measures to encourage rational use of scarce environmental resources and to avoid distortions in international trade and investment is the so-called "Polluter-Pays Principle." This principle means that the polluter should bear the expenses of carrying out the [environmental] measures decided by public authorities to ensure that the environment is in an acceptable state. In other words, the cost of these measures should be reflected in the cost of goods and services that cause pollution in production and/or consumption. Such measures should not be accompanied by subsidies that would create significant distortions in international trade and investment. ${ }^{22}$

In 1973 the OECD also issued a Note on the Implementation of the Polluter-Pays Principle, explaining that under the principle, "the polluter should bear the expenses of preventing and controlling pollution 'to ensure that the environment is in an acceptable state,'" which will be determined by public authorities. "In fact, the Polluter-Pays Principle is no more than an efficiency principle for allocating costs and does not involve bringing pollution down to an optimum level of any type, although it does not exclude the possibility of doing so." 23

The principle was later enshrined in the 1992 Rio Declaration on Environment and Development (Rio Declaration). The Rio Declaration came out of the United Nations Conference on Environment and Development, also known as the "Earth Summit" or the "Rio Conference," held in Rio de Janeiro, Brazil, in June 1992. ${ }^{24}$ The Rio Declaration consists of a short preamble followed by twenty-seven principles for sustainable development. Principle 16 of the Rio Declaration provides:

\footnotetext{
${ }^{21}$ Jonathan Remy Nash, Too Much Market? Conflict Between Tradable Pollution Allowances and the Polluter Pays Principle, 24 HARV. ENVTL. L. REV. 465, 468 (2000).

${ }^{22}$ OECD, Environment and Economics: Guiding Principles Concerning International Economic Aspects of Environmental Policies, May 26, 1972, annex para. 1 Doc. No. C(72)128, 1972 WL 24710. ${ }^{23}$ Note on the Implementation of the Polluter-Pays Principle, OECD Env't Committee (1973).

${ }^{24}$ See DUPUY \& VIÑUALES, supra note 20 at 13-14.
} 
National authorities should endeavor to promote the internalization of environmental costs and the use of economic instruments, taking into account the approach that the polluter should, in principle, bear the cost of pollution, with due regard to the public interest and without distorting international trade and investment. ${ }^{25}$

Polluter pays has been influential in holding polluters accountable and internalizing the costs of pollution, ${ }^{26}$ and has been embraced in international tribunals. For example, the Court of Justice of the European Union has described polluter pays as a "principle of environmental law" and held that the principle justifies requiring airlines to surrender emissions allowances at a variable rate based on miles traveled. ${ }^{27}$ In a case concerning nuclear weapons, a judge of the International Court of Justice (ICJ) similarly noted that "the 'polluter pays principle' [places] on the author of environmental damage the burden of making adequate reparation to those affected." 28

${ }^{25}$ United Nations Conference on Environment and Development, Rio de Janiero, Braz., June 3-14, 1992, Rio Declaration on Environment and Development, U.N. Doc A/Conf.151/26 (1992), 31 I.L.M. 874, 876 (1992) [hereinafter "Rio Declaration"].

${ }^{26}$ Armin Rosencraz et al., The Evolution and Influence of International Environmental Norms, 49 ENVTL. L. REP. NEWS \& ANALYSIS 10125, 10129 (2019); DAVID HUNTER ET AL., INTERNATIONAL ENVIRONMENTAL LAW AND POLICY 517 (3d ed. Foundation Press, 2007).

${ }^{27}$ Case C-366/10, Air Transp. Ass'n of America v. Sec'y of State for Energy and Climate Change, ECLI:EU:C:2011:864, II 153 (Dec. 21, 2011) (“[A] particular airline may be required, when departing from or arriving at a European aerodrome, to surrender emission allowances that are higher the further the point of departure is from the destination. Taking account of the whole length of the flight is ultimately an expression of the principle of proportionality and reflects the 'polluter pays' principle of environmental law."); see also Suzanne Kingston, The Polluter Pays Principle in EU Climate Law: An Effective Tool Before the Courts? 22 (UCD Working Papers in Law, Criminology \& Socio-Legal Studies, 2020), https://ssrn.com/abstract=3671375 ("The PPP forms an essential part of the constitutional framework for EU environmental policy and, as soft law hardens into legislation and binding targets, judges will be required to answer difficult questions about its implications.") ${ }_{28}$ Threat or Use of Nuclear Weapons, Advisory Opinion, Dissenting Opinion of Weeramantry, J. 1996 I.C.J. 503 (July 8); see also Certain Activities Carried out by Nicaragua in the Border Area (Nicar. v. Costa Rica) and Construction of a Road in Costa Rica Along the San Juan River (Nicar. v. Costa Rica), Separate Opinion of Bhandari, J., 2015 I.C.J. 796 (Dec 16) (noting that the polluter pays principle "does not have the status of a principle of general international law" but that it "acts as merely a general guideline of public international law.") (citations omitted). 
The IMO has recognized the "'polluter pays' principle as a general principle of international environmental law." ${ }^{29}$ A number of IMO conventions incorporate the polluter pays principle. For example, the International Convention on Civil Liability for Oil Pollution was adopted to ensure compensation to persons who suffer oil pollution damage resulting from maritime casualties involving oil-carrying ships, and places liability for damage on the owner of the ship from which oil escaped or was discharged. ${ }^{30}$ The International Convention on Civil Liability for Bunker Oil Pollution Damage similarly holds ship owners liable for pollution damage caused by any bunker oil on board or originating from its ship, and seeks to ensure adequate and effective compensation for such damage. ${ }^{31}$

There are several advantages to relying on the polluter pays principle for adopting an MBM to reduce GHG emissions from shipping. One is that, as discussed, it is widely accepted, including by the IMO. Additionally, polluter pays allows the assignment of responsibility to individuals or companies rather than states. ${ }^{32}$ Even if the IMO's mechanism is ultimately implemented by statesfor example, if states allocate allowances among regulated entities-the objective is for shipping companies, rather than governments, to bear the costs.

Moreover, the polluter pays principle is suitable to the problem of climate change because it is not confined to scenarios in which one company emits a conventional pollutant that causes harm to one victim. Rather, the principle can be incorporated into an MBM to address pollution that harms the general environment. This applies to cases of "aggregate pollution loading," in which multiple polluters are responsible and it is difficult to identify particular victims; the government then serves as a proxy for the victimized society. In such circumstances, the polluter pays principle counsels that each polluter should internalize the costs of pollution by reimbursing the government for the

\footnotetext{
${ }^{29}$ International Maritime Organization: International Convention on Oil Pollution Preparedness, Response and Co-Operation, 1990, and Final Act of the Conference, Nov. 30, 1990, 30 I.L.M. 733, 736 (1991).

30 See International Convention on Civil Liability for Oil Pollution Damage, Nov. 29, 1969, 973 U.N.T.S. 3.

31 See Adoption of the International Convention on Civil Liability for Bunker Oil Pollution Damage, Agenda Item 8, 27 December 2015, LEG/CONF.12/19.

32 See DUPUY \& VIÑUALES, supra note 20 at 82.
} 
expense of addressing the problem. ${ }^{33}$ Here, the IMO stands in for the government, and can require shipping companies to internalize the costs of greenhouse gas emissions by levying a carbon tax.

Indeed, the polluter pays principle arguably provides the basis for the Carbon Offsetting and Reduction Scheme for International Aviation (CORSIA). CORSIA is the carbon pricing scheme that the International Civil Aviation Organization (ICAO) adopted in 2016 to stabilize emissions from aircraft, following the Kyoto Protocol's delegation of authority to ICAO to address greenhouse gases from the aviation sector. ${ }^{34}$ Arguably, the IMO has even more authority than ICAO to implement such an MBM. As discussed, the IMO has express authority to adopt measures to address "marine pollution," whereas ICAO adopted measures to deal with aviation greenhouse gas emissions under the umbrella of regulating safety and efficiency of air navigation. ${ }^{35}$

For these reasons, the polluter pays principle provides strong support to the IMO's authority to adopt a market-based mechanism to reduce greenhouse gas emissions from shipping.

\section{PARIS CLIMATE AGREEMENT PRINCIPLE OF HIGHEST AMBITION}

The Principle of Highest Ambition comes from the Paris Agreement, an international accord to implement the goals of the United Nations Framework Convention on Climate Change (UNFCCC). ${ }^{36}$ The parties to the Paris Agreement seek to hold the increase in global average temperatures to well below two degrees Celsius, and to pursue efforts to limit the temperature rise to 1.5 degrees above pre-industrial levels. ${ }^{37}$ Parties are required to periodically submit nationally determined contributions (NDCs) stating the GHG emissions reductions that they plan to contribute to these overarching goals. ${ }^{38}$ Article 4(3) of the Paris Agreement states:

\footnotetext{
33 See Nash, supra note 21, at 478.

34 See generally Thomas Leclerc, A Sectoral Application of the Polluter Pays Principle: Lessons Learned from the Aviation Sector, 9 CLIMATE LAW 303-25 (2019).

35 See O'Leary \& Brown, supra note 13, at 8 (discussing comparison between ICAO's CORSIA system and a potential MBM under IMO Convention).

${ }^{36}$ Adoption of the Paris Agreement, Decision 1/CP.21, 12 December 2015, FCCC/CP/2015/L.1, art. 4(3) [hereinafter "Paris Agreement"].

${ }^{37} \mathrm{Id}$. art. 2(1)(a).

${ }^{38} I d$. art. 4.
} 
Each Party's successive nationally determined contribution will represent a progression beyond the Party's then current nationally determined contribution and reflect its highest possible ambition, reflecting its common but differentiated responsibilities and respective capabilities, in the light of different national circumstances. ${ }^{39}$

The Paris Agreement thus heightens the urgency of the global task to reduce emissions from all sectors. ${ }^{40}$ Some see the principle of highest ambition as assigning states a duty of care, taking into account their respective common but differentiated responsibilities and national circumstances (discussed infra). ${ }^{41}$ Because the principle of highest ambition holds states to a stringent standard of emissions reduction, it provides a basis for the IMO to seek steep cuts in shipping emissions and fulfill its goal of achieving reductions consistent with the temperature goals of the Paris Agreement.

Although the principle of highest ambition is not expressly mentioned in MARPOL or the IMO Convention, the IMO Convention does instruct the Organization to "encourage the general adoption of the highest practicable standards in matters concerning maritime safety and efficiency of navigation." 42 This provision is arguably akin to the principle of highest ambition, particularly given that climate disruption threatens maritime safety (through more extreme storms, damage to port infrastructure, and other factors) and efficiency is a primary means of reducing shipping GHGs. Moreover, the IMO Initial GHG Strategy references the Paris Agreement temperature goals. ${ }^{43}$ The IMO Initial GHG Strategy also explicitly aims to enhance the IMO's contribution to global efforts including the Paris Agreement. ${ }^{44}$ Furthermore, "[t]he Paris Agreement is a temperature-based target and therefore implies inclusion of all emissions that affect climate." 45 If shipping emissions are

${ }^{39} \mathrm{Id}$. art. 4(3).

40 See O'Leary \& Brown, supra note 13 at 4.

${ }^{41}$ Christina Voigt \& Felipe Ferreira, 'Dynamic differentiation': The Principles of CBDRRC-RC, Progression and Highest Possible Ambition in the Paris Agreement, 5 TRANSNAT'L ENVTL. LAW 297 (2016).

${ }^{42}$ IMO Convention, Pt. 1, art. 1(a).

${ }^{43}$ Marine Envtl. Prot. Comm. [MEPC], Initial IMO Strategy on Reduction of GHG Emissions from Ships, MEPC Res. 304(72) (Apr. 13, 2018) [hereinafter IMO Initial GHG Strategy], https://wwwcdn.imo.org/localresources/en/KnowledgeCentre/IndexofIMOResolutions/MEPCDoc uments/MEPC.304(72).pdf.

${ }^{44} I d$.

${ }^{45}$ DAVID S. LEe, INTERNATIONAL AVIATION AND THE PARIS AgREEMENT TEMPERATURE GOAls 1 (Dec. 2018) (commissioned by the UK Department for Transport). 
permitted to rise unchecked, they could seriously interfere with the achievement of the Paris temperature targets. In fact, the IMO has determined that GHG emissions from international shipping could grow by $90-130 \%$ by $2050 .{ }^{46}$ The principle of highest ambition thus creates an imperative to address GHG emissions from the shipping sector, consistent with the objectives of the Paris Agreement and the UNFCCC.

\section{COMMON BUT DIFFERENTIATED RESPONSIBILITIES AND RESPECTIVE CAPABILITIES}

The principle of common but differentiated responsibilities and respective capabilities (CBDRRC), in the light of the different national circumstances, provides that developed and developing countries may have different levels of responsibility to respond to international environmental problems, though all have some responsibility. The principle aims to distribute the effort required to manage environmental problems of a global nature among states on the basis of two criteria: responsibilities and capabilities. Responsibilities include both historical and present responsibilities, and capabilities include both financial and technical. Put differently, the principle of CBDRRC recognizes that some states have contributed more to certain environmental problems, and that some states have greater capacity to address those problems, and seeks to allocate responsibility based on those respective contributions and capacities. ${ }^{47}$

Some commenters view CBDRRC as the flipside of the concept that certain environmental processes or protective actions raise common concerns, triggering obligations on all states and the need for international cooperation. CBDRRC purports to moderate the common obligations of all states by taking a more nuanced approach to cooperation that recognizes inequalities between developed and developing states. ${ }^{48}$

The concept of common but differentiated responsibilities first appeared in the 1985 Vienna Convention for the Protection of the Ozone Layer, which refers to the "circumstances and particular

${ }^{46}$ Fourth IMO GHG Study, supra note 1 at 12.

47 See DUPUY \& VIÑUALES, supra note 20 at 83 (citing Vienna Convention for the Protection of the Ozone Layer preamble II 5, March 22, 1985, 1513 U.N.T.S. 293. [hereinafter “Vienna Convention”]). 48 DANiEl BODANSKy ET AL., INTERNATIONAl Climate ChANGE LAW 51-52 (Oxford University Press 2017). 
requirements of developing countries." ${ }^{49}$ The Vienna Convention also requires countries to fulfill their obligations "in accordance with the means at their disposal and their capabilities" and cooperate with respect to technology transfer. ${ }^{50}$ The Rio Declaration formalized the principle of common but differentiated responsibilities, stating that:

States shall cooperate in a spirit of global partnership to conserve, protect and restore the health and integrity of the Earth's ecosystem. In view of the different contributions to global environmental degradation, States have common but differentiated responsibilities. The developed countries acknowledge the responsibility that they bear in the international pursuit of sustainable development in view of the pressures their societies place on the global environment and of the technologies and financial resources they command. ${ }^{51}$

While not yet formally embraced as customary international law, ${ }^{52}$ the principle of common but differentiated responsibilities has since been incorporated into a number of international legal instruments. The principle was formulated in the climate regime with the additional concept of respective capabilities, resulting in CBDRRC. Article 3 of the UNFCCC provides:

The Parties should protect the climate system for the benefit of present and future generations of humankind, on the basis of equity and in accordance with their common but differentiated responsibilities and respective capabilities. Accordingly, the developed country Parties should take the lead in combating climate change and the adverse effects thereof. ${ }^{53}$

The UNFCCC expands on the conception of CBDRRC espoused in the Rio Declaration. Whereas the Rio Declaration focuses on countries' disparate contributions to environmental degradation, the UNFCCC also recognizes the unequal capabilities between developed and developing countries. The differentiation as envisioned by the UNFCCC is thus a function not only of countries' different emissions levels, but also their distinct capacities to address climate change. The Kyoto Protocol to the UNFCCC gave effect to this principle by requiring developed countries to meet quantified emissions targets and imposing no such obligations on developing countries. ${ }^{54}$

\footnotetext{
${ }^{49} \mathrm{Id}$. at 84-85 (quoting Vienna Convention, preamble II 5).

${ }^{50} I d$. at 85 (quoting Vienna Convention, arts. 2(2), 4(2)).

51 See Rio Declaration, Principle 7; see also Roger R. MARTElla, JR. \& BretT BrosKO,

INTERNATIONAL ENVIRONMENTAL LAW 979 (American Bar Association 2014).

52 BODANSKY ET AL., supra note 48 at 52.

${ }^{53}$ United Nations Framework Convention on Climate Change art. 3(1), May 9, 1992, 1771 U.N.T.S. 107 [hereinafter "UNFCCC"].

${ }^{54}$ Kyoto Protocol at art. 3(1).
} 
While the Paris Agreement recognizes the principle of CBDRRC, it does not actually implement the principle with respect to states' emissions reductions commitments. ${ }^{55}$ The Paris Agreement uses a lighter touch by not imposing specific emissions reduction obligations on states, but instead calling on each country to put forward emission reduction pledges, and urging the developed countries and others to provide financial assistance to developing countries in recognition of the latter's relatively limited capacities. ${ }^{56}$ However, "[t]he principle of CBDRRC . . . guides the further normative development of the climate regime, notwithstanding ongoing contestations over the correct interpretation of the principle and its future," and differentiation has, for example, been incorporated into the ICAO MBM for reducing emissions from international aviation..$^{57}$

Some IMO documents have recognized and incorporated CBDRRC. For example, the Convention on the Prevention of Marine Pollution by Dumping of Wastes and Other Mattersknown as the London Convention-requires contracting parties to "take effective measures, according to their scientific, technical and economic capabilities, to prevent, reduce and where practicable eliminate pollution." ${ }^{58}$ During the developments of the 2011 Annex VI amendments to MARPOL, which apply to air pollution from ships, some states argued that CBDRRC should apply to differentiate the limits on maritime pollution for developed and developing countries. However, developed countries argued that CBDRRC conflicts with the principle of nondiscrimination (discussed infra), and that the latter should control. The IMO secretariat took the position that the two principles do not conflict, because CBDRRC applies to countries while nondiscrimination applies to ships. Developed countries ultimately prevailed; the amendments apply equally to all vessels, although developing nations were able to waive them for four years. ${ }^{59}$ The IMO

\footnotetext{
${ }^{55}$ Paris Agreement, preamble, arts. 2(2), 4(4); see also BODANSKY ET AL., supra note 48 at 221.

56 See DUPUY \& VIÑUALES, supra note 20 at 85; Paris Agreement, art. 2(1)(c).

${ }^{57}$ Beatriz Martinez Romera and Harro van Asselt, The International Regulation of Aviation Emissions, 27 JOURNAL OF ENVT'L LAW 271, 282 (July 2015).

${ }^{58}$ Convention on the Prevention of Marine Pollution by Dumping of Wastes and Other Matter, 1972, art. 2, 1046 U.N.T.S. 120, https://wwwcdn.imo.org/localresources/en/OurWork/Environment/ Documents/LC1972.pdf [hereinafter “London Convention"].

${ }^{59}$ BODANSKY ET AL., supra note 48 at 269.
} 
subsequently adopted a resolution on technology transfer and capacity building for energy efficiency in part to address this issue. ${ }^{60}$

Most relevant to the issue at hand, the IMO's GHG Initial Strategy explicitly recognizes the need to "be cognizant of the principles enshrined in instruments already developed, such as ... the principle of common but differentiated responsibilities and respective capabilities, in the light of different national circumstances." ${ }^{61}$ CBDRRC also counsels that countries that have contributed the most to climate change have greater responsibility. ${ }^{62}$

CBDRRC is widely recognized in international law, and although it has not always prevailed at the IMO, it is expressly incorporated into the IMO's Initial GHG Strategy. ${ }^{63}$ While the principle might not specifically provide the authority to adopt an MBM, the concept of CBDRRC can shape the way in which an MBM is operationalized. For example, some have argued that a carbon-pricing scheme to reduce international shipping emissions should include a fund that allocates money to developing countries in order to respect CBDRRC. ${ }^{64}$ The principle thus justifies allocating the revenue from any market-based mechanism to vulnerable nations in recognition of their relatively limited capacity to address the problem of climate change and their national circumstances; andto the extent feasible within the IMO's frameworks - requiring greater action on the part of countries that have contributed the most to global greenhouse gas emissions.

\footnotetext{
${ }^{60}$ MEPC, Promotion of Technical Cooperation and Transfer of Technology Relating to the Improvement of Energy Efficiency of Ships, Annex 4, MEPC Doc. 65/22 (May 17, 2013), https://bit.ly/37SH6Vt.

${ }^{61}$ IMO Initial GHG Strategy, supra note 43 III 3.2.1.1 - .2.

${ }^{62}$ It is worth noting that "making a definitive association between a particular ship and a particular country for the purposes of CBDR-RC is complicated because a ship's flag; the routes it sails on; where it refuels; and the registration or nationality of the ships' owners, charterers, and ship financers are not necessarily related." NEW CLIMATE INSTITUTE, AKI KACHI, SILKE MOOLDIJK, CARSTEN WARNECKE, CARBON PRICING OPTIONS FOR INTERNATIONAL MARITIME EMISSIONS 25 (March 2019).

${ }^{63}$ Some have argued that the IMO must expressly incorporate CBDRRC into its rule. See, e.g., Stathis N. Palassis, The IMO's Climate Change Challenge: Application of the Principle of Common but Differentiated Responsibilities and Respective Capabilities, 6 WASH. \& LEE J. ENERGY CLIMATE \& ENV'T 160, 190 (2014). ${ }^{64}$ See, e.g., NEW ClIMATE INSTITUTE, supra note 62 at 25.
} 


\section{PRECAUTIONARY PRINCIPLE}

The notion of precaution provides that the lack of scientific uncertainty about the actual or potential effects of an activity must not prevent states from taking appropriate measures when such effects may be serious or irreversible. ${ }^{65}$ It is enshrined in the Rio Declaration, which provides:

In order to protect the environment, the precautionary approach shall be widely applied by States according to their capabilities. Where there are threats of serious or irreversible damage, lack of full scientific certainty shall not be used as a reason for postponing cost-effective measures to prevent environmental degradation. ${ }^{66}$

The principle has been incorporated into the $\mathrm{UNFCCC}^{67}$ and other multilateral treaties, ${ }^{68}$ and recognized by at least one international court. ${ }^{69}$

In the specific context of IMO resolutions, the precautionary principle is discussed in juxtaposition with the need for evidence-based decision making. The IMO Convention provides, in Article 1, that the IMO should "provide machinery ... to encourage and facilitate the general adoption of the highest practicable standards in ... prevention and control of marine pollution from ships."70 Moreover, in its most recent strategic plan, the IMO reiterates that the mission of the agency is, in part, to promote "environmentally sound, efficient and sustainable shipping . . . by adopting the highest practicable standards of ... prevention and control of pollution from ships."71

\footnotetext{
65 DUPUY \& VIÑUALES, supra note 20 at 70.

${ }^{66}$ Rio Declaration, Principle 15.

${ }^{67}$ UNFCCC art. 3(3).

68 See, e.g., Agreement for the Implementation of the Provisions of the United Nations Convention on the Law of the Sea of 10 December 1982 Relating to the Conservation and Management of Straddling Fish Stocks and Highly Migratory Fish Stocks art. 6, Aug. 4, 1995, 2167 U.N.T.S. 88 (calling for a "precautionary approach"); Cartagena Protocol on Biosafety to the Convention on Biodiversity arts. 1 and 10(6), Jan. 29, 2000, 2226 U.N.T.S. 208 (same).

69 Tatar v. Romania, App. No. 67021/01, II 120 (July 6, 2009), http://hudoc.echr.coe.int/eng?i=00190981 (recognizing the importance of the precautionary principle).

${ }^{70}$ IMO Convention art. 1(a).

${ }^{71}$ Int'1 Maritime Org. [IMO] A. 1110 (30), Six Year Strategic Plan for 2018-2023 (Dec. 8, 2017),

https://wwwcdn.imo.org/localresources/en/KnowledgeCentre/IndexofIMOResolutions/AssemblyD ocuments/A.1110(30).pdf; see also Marine Envtl. Prot. Comm. [MEPC], Comments on the Fourth IMO GHG Study 2020 and Encouraging Further Ambitious Action to Reduce GHG Emissions Submitted by the Marshall Islands and Solomon Islands II 2, MEPC Doc. 75/7/17 (Sept. 25, 2020), https://docs.imo.org/ Shared/Download.aspx?did=125766 (noting without citation that "[d]ecisions in IMO must be taken in light of the best available science").
} 
A resolution titled "Guidelines on Incorporation of the Precautionary Approach in the Context of Specific IMO Activities" caveats the IMO's application of the precautionary principle with the need to wait to act until there is a "compelling need." There, the MEPC explains that:

if a precautionary approach is to be routinely incorporated into the work of IMO [it] should ensure:

1. anticipation and prevention of environmental problems arising from any regulatory activities of IMO and striving for continual improvement in all facets of those activities;

2. that solutions to problems and consideration of new and existing policies, programmes, guidelines and regulations are developed in accordance with the precautionary approach;

3. that, where action is necessary and options may involve uncertainty, all options are evaluated consistent with the precautionary approach;

8. consideration and adoption of economic incentives to encourage environmental responsibility so as to conserve the marine environment and avoid its further degradation[.] $]^{72}$

Immediately following its detailed explanation of what the precautionary approach requires, the MEPC adds that "[t]he precautionary approach should not be considered in isolation of other IMO practices, procedures and resolutions, including resolutions A.500 and A.777 and principles such as the "polluter pays' principle." 73 Each of the Assembly resolutions the MEPC cites here requires "the Council and the Committees [to] entertain proposals for new conventions or amendments to existing conventions only on the basis of clear and well documented demonstration of compelling need ... and having regard to the costs ... and the burden on the legislative and

\footnotetext{
${ }_{72}$ Marine Envtl. Prot. Comm. [MEPC] Resolution 67 (37), Guidelines on Incorporation of the Precautionary Approach in the Context of Specific IMO Activities II 4 (Sept. 15, 1995), https://wwwcdn.imo.org/localresources/en/KnowledgeCentre/IndexofIMOResolutions/MEPCDoc uments/MEPC.67(37).pdf.

${ }^{73} I d$.
} 
administrative resources of Member States."74 Although these guidelines are now over twenty-five years old and arguably in tension with the Organization's mission to encourage the highest practicable standard for reducing pollution from ships, the MEPC's 2018 initial strategy for GHG reductions explicitly cites these guidelines. The strategy reiterates that the IMO's GHG reductions strategy should be guided by, among others, "the need for evidence-based decision-making balanced with the precautionary approach as set out in [the resolution discussed above]."75

The precautionary principle is included in the Initial Strategy to make it possible for the IMO to act even without complete data. But because IMO practice limits the use of the precautionary principle by noting that it will not be considered apart from other principles, precaution is likely not the strongest basis on which to base the IMO's authority to act. However, the precautionary principle does not merely justify intervention to prevent pollution. It can also provide a framework for that intervention by heightening the standard of due diligence required in the face of environmental harms that might be serious or irreversible. ${ }^{76}$ Arguably, this is the most appropriate role for the precautionary principle in the climate change context, given that no real uncertainty exists as to whether greenhouse gases are harmful or cause serious and potentially irreversible impacts. In this case, the principle can therefore play a role in setting the price of carbon within the MBM that is

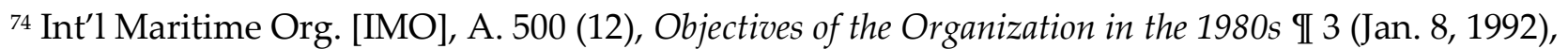
https://wwwcdn.imo.org/localresources/en/KnowledgeCentre/IndexofIMOResolutions/AssemblyD ocuments/A.500(12).pdf; see also Int'1 Maritime Org. [IMO], A. 777 (18), Work Methods and Organization of Work in Committees and Their Subsidiary Bodies II 4 (Nov. 4, 1993), https://wwwcdn.imo.org/localresources/en/KnowledgeCentre/IndexofIMOResolutions/AssemblyD ocuments/A.777(18).pdf (inviting "the attention of the Committees to resolution A.500(XII) and in particular its recommendation that proposals for new conventions or amendments to existing conventions be entertained only on the basis of clear and well-documented compelling need"); see also Int'l Maritime Org. [IMO], Doc. BMW/CONF/36, International Convention for the Control and Management of Ship's Ballast preamble (Feb. 16, 2004), https://treaties.un.org/doc/Publication/UNTS/ No\%20Volume/55544/Part/I-55544-080000028053b465.pdf; Int'1 Maritime Org. [IMO], Res. LDC 44 (14), The Application of a Precautionary Approach in Environmental Protection Within the Framework of the London Dumping Convention II 1 (Dec. 30, 1991), https://wwwcdn.imo.org/localresources/en/ KnowledgeCentre/IndexofIMOResolutions/LCLPDocuments/LDC.44(14).pdf. Moreover, the IMO's identification of Particularly Sensitive Sea Areas is arguably based on the precautionary principle. See Int'l Maritime Org. [IMO], A. 500 (12), A. 982 (24), Revised Guidelines for the Identification and Designation of Particularly Sensitive Sea Areas (Feb. 6, 2006), https://wwwcdn.imo.org/localresources/ en/OurWork/Environment/Documents/A24-Res.982.pdf.

${ }^{75}$ IMO Initial GHG Strategy, supra note 43.

76 See BODANSKY ET AL., supra note 48 at 53. 
adopted, as the IMO must seek to achieve emissions reductions that will contribute to averting serious and irreversible harms.

\section{TRANSBOUNDARY POLLUTION AND THE NO-HARM PRINCIPLE}

The treatment of transboundary pollution evolved from the no-harm rule, a foundational background principle of international law. The no-harm rule provides that states' sovereign right to use their territories and resources is constrained by their obligation to avoid doing serious harm outside of their boundaries. ${ }^{77}$

The Trail Smelter case is the first international case to apply this principle to transboundary air pollution. The case arose after sulfur dioxide emission from a zinc and lead smelter in British Columbia damaged private agricultural forest properties in the U.S. State of Washington. The U.S. and Canadian governments referred the case to the International Joint Commission. In 1931, the Commission found that the smelter had caused property damage and awarded $\$ 350,000$. The Canadian government accepted liability, but the U.S. Government rejected the award, seeking to have the Trail Smelter enjoined from operating. Arbitration continued, and in 1941 an ad hoc tribunal concluded that not only could Canada be held liable for the damage, but that the nation could also be compelled to force the Trail Smelter to close. The tribunal found:

under the principles of international law, as well as of the law of the United States, no State has the right to use or permit the use of its territory in such a manner as to cause injury by fumes in or to the territory of another or the properties or persons therein, when the case is of serious consequence and the injury is established by clear and convincing evidence. ${ }^{78}$

The decision's principles are now reflected throughout international law. ${ }^{79}$ The no-harm rule's application to environmental damage has since been recognized in a number of international legal instruments and cases.

77 See BODANSKY ET AL., supra note 48 at 40.

78 See HUNTER ET AL., supra note 26 at 543-46 (quoting United States v. Canada, Arbitral Tribunal, 1941, 3 UN Rep. Int'l Arb. Awards (1941)).

${ }^{79}$ MARTELLA \& BROSKO, supra note 51 at 62. 
The 1972 Stockholm Declaration on the Human Environment, the first multilateral statement of international environmental law principles, is considered to mark the beginning of international environmental law. ${ }^{80}$ Principle 21 of the Stockholm Declaration-described as "the cornerstone of international environmental law" ${ }^{\prime \prime}$ - provides as follows:

States have, in accordance with the Charter of the United Nations and the principles of international law, the sovereign right to exploit their own resources pursuant to their own environmental policies, and the responsibility to ensure that activities within their jurisdiction or control do not cause damage to the environment of other States or of areas beyond the limits of national jurisdiction. ${ }^{82}$

Principle 2 of the Rio Declaration contains almost identical language, but incorporates the right to economic development by referring to states' “own environmental and developmental policies." 83

The ICJ affirmed in 1996 that "the general obligation of States to ensure that activities within their jurisdiction and control respect the environment of other States or of areas beyond national control is now part of the corpus of international law relating to the environment." 84 The ICJ clarified in 2010 that this principle is customary international law. ${ }^{85}$

Moreover, it is also now commonly accepted that the no-harm rule applies beyond injuries that one state can inflict on another. In 1970 the ICJ concluded that states have "certain obligations towards the international community as a whole," otherwise known as the ergo omnes, a concept that has become widely recognized. ${ }^{86}$ The ICJ has repeatedly confirmed that, in general, the no-harm rule applies to environmental impacts. ${ }^{87}$ Moreover, as discussed, the no-harm principle as articulated in

\footnotetext{
${ }^{80}$ MARTELLA \& BROSKO, supra note 51 at 978.

${ }^{81}$ MARTElla \& BROSKO, supra note 51 at 978 (quoting PhILIPPE SANDS \& JACQUELINE PeEL, PRINCIPLES OF INTERNATIONAL ENVIRONMENTAL LAW 191 (3d ed. 2012)).

82 Stockholm Declaration on the Human Environment, UN Doc. A/Conf. 48/14/Rev., 11 ILM 1416 (1972), Principle 21 (emphasis added) [hereinafter "Stockholm Declaration"].

${ }^{83}$ Rio Declaration, Principle 2 (emphasis added).

${ }^{84}$ Legality of the Threat or Use of Nuclear Weapons, Advisory Opinion, 1996 I.C.J. 226, 242, II 29 (July 8).

${ }^{85}$ See Case concerning Pulp Mills on the River Uruguay, Judgment, 2010 I.C.J. 14, II 101 (April 20).

86 I.C.J. Reports, 1970, Barcelona Traction, Light and Power Company, Limited (Belgium v. Spain) (1962-1970), Second Phase, Judgment, I.C.J Reports 1970.

${ }^{87}$ BODANSKY ET AL., supra note 48 at 49.
} 
the Stockholm Declaration and the ICJ calls on states to avoid causing harm to other states or to areas outside their jurisdiction, suggesting an obligation to protect the global commons.

The IMO has expressly embraced the no-harm principle in the context of pollution from ships, while recognizing that states have a common interest to protect the general environment. The London Convention recognizes:

that the marine environment and the living organisms which it supports are of vital importance to humanity, and all people have an interest in assuring that it is so managed that its quality and resources are not impaired.

And further recognizes:

that States have, in accordance with the Charter of the United Nations and the principles of international law, the sovereign right to exploit their own resources pursuant to their own environmental policies, and the responsibility to ensure that activities within their jurisdiction or control do not cause damage to the environment of other States or of areas beyond the limits of national jurisdiction. ${ }^{88}$

The no-harm principle is commonly recognized in-even considered a bedrock principle of-international environmental law. The principle has been interpreted to impose an obligation on states to avoid environmental damage to other nations and the global commons, and has been adopted by the IMO. Further, the principle can apply to a problem like climate change, in which harm is done to the global environment, rather than directly to another state. The principle also obliges states to prevent harm caused by activities within their jurisdiction or control. Because the principle is not constrained by borders, it suggests that states have an obligation to rein in any shipping emissions over which they have some authority. For these reasons, the principle provides a sound basis for the IMO to adopt an MBM to address GHG emissions from shipping.

\section{INTERGENERATIONAL EQUITY}

Intergenerational equity refers to the principle of balancing the current generation's needs with the duty to preserve resources for future generations. The 1946 International Convention for the Regulation of Whaling represents an early articulation of this principle in international law. The Convention for the Regulation of Whaling referenced the interest of "nations of the world in

${ }^{88}$ London Convention, preamble. 
safeguarding for future generations the great natural resources represented by the whale stocks." 89 Principle 1 of the Stockholm Declaration subsequently declared that "[t]o defend and improve the human environment for present and future generations has become an imperative goal for mankind." 90

The Rio Declaration marks a shift towards the modern conception of the principle, which places greater emphasis on the present generation's interest in exploiting resources. Principle 3 of the Rio Declaration affirms that "[ $t$ ]he right to development must be fulfilled so as to equitably meet developmental and environmental needs of present and future generations." ${ }^{91}$ While the principle of intergenerational equity is not explicitly mentioned in any IMO documents identified, the London Convention alludes to this notion by recognizing that "the capacity of the sea to assimilate wastes and render them harmless, and its ability to regenerate natural resources, is not unlimited."92 The IMO has also committed to "actively working towards the 2030 Agenda for Sustainable Development and the associated" Sustainable Development Goals, and has recognized that "[t]he Sustainable Development Goals provide a blueprint for the transition to a healthier planet ... for present and future generations." 93

In the climate change context, the UNFCCC calls on parties to "protect the climate system for the benefit of present and future generations of humankind." 94 In some countries, youth have brought rights-based lawsuits against their national governments - on behalf of themselves as well as future generations-alleging insufficient action on climate change. ${ }^{95}$ The principle of

${ }^{89}$ DUPUY \& VIÑUALES, supra note 20 at 88 (quoting the International Convention for the Regulation of Whaling with Schedule of Whaling Regulations preamble II 1, Dec. 2, 1946, 161 U.N.T.S. 361).

${ }^{90}$ Stockholm Declaration, Principle 1.

${ }^{91}$ DUPUY \& VIÑUALES, supra note 20 at 88-89 (quoting Rio Declaration, Principle 3).

${ }^{92}$ Dumping Convention, preamble.

${ }^{93} \mathrm{IMO}$, IMO and the Sustainable Development Goals, (visited Feb. 10, 2021), https://www.imo.org/en/MediaCentre/HotTopics/Pages/SustainableDevelopmentGoals.aspx. ${ }^{94}$ UNFCCC, article 3.1

95 See, e.g., Mathur v. Ontario, 2020 ONSC 6918, CV-19-00631627 (Superior Ct. of Justice, Ontario, 2020); Supreme Court of Colombia, Apr. 4, 2018, Future Generations v. Ministry of Environment et al., STC 4360-2018, 1101-22-03-000-2018-00318-01 [hereinafter Future Generations]. 
intergenerational equity has been recognized by some national courts, including in Colombia, Australia, the Philippines, Chile, and India. ${ }^{96}$

The principle of intergenerational equity creates a clear imperative to reduce greenhouse gases, given the indisputable evidence that failure to do so will cause damage and suffering to future generations. The principle therefore provides support to the IMO to impose emissions reductions that are consistent with the Paris Agreement's temperature goals.

\section{RIGHT TO LIFE AND RIGHT TO FAMILY LIFE}

The Right to Life is enshrined in all international human rights instruments, including the International Covenant on Civil and Political Rights, the European Convention on Human Rights, the African Charter on Human and People's Rights, and the American Declaration of the Rights and Duties of Man. ${ }^{97}$ The Rio Declaration also provides that "[h]uman beings are ... entitled to a healthy and productive life in harmony with nature." 98

The right to life has been interpreted to encompass the right to a clean environment, or at least, an environment that does not pose a threat to one's health. For example, the African Commission on Human and People's Rights found that by promoting oil development in Ogoniland - which caused short- and long-term health impacts including increased risk of cancerthe Nigerian government violated the right to life. ${ }^{99}$ In a report on pollution in Ecuador, the InterAmerican Commission on Human Rights similarly explained that "[ $t$ ]he realization of the right to life, and to physical security and integrity is necessarily related to and in some ways dependent upon

\footnotetext{
${ }^{96}$ See Future Generations, supra note 95; SVITLANA KRAVCHENKO, HuMAN RIGHTS AND THE ENVIRONMENT 69-70, 590 (Carolina Academic Press 2008).

97 See International Covenant on Civil and Political Rights art. 6, Dec. 16, 1966, 999 U.N.T.S. 171 [hereinafter "International Covenant on Civil and Political Rights"]; Convention for the Protection of Human Rights and Fundamental Freedoms, Nov. 4, 1990, 213 U.N.T.S. 222; African Charter on Human and Peoples' Rights, O.A.U. Doc. CAB/LEG/67/3 rev. 5; 21 I.L.M. 58 (1982); American Declaration of the Rights and Duties of Man, O.A.S. Res. XXX, adopted by the Ninth International Conference of American States (1948); see also KRAVCHENKO, supra note 96 at 23.

${ }_{98}^{8}$ Rio Declaration, Principle 1.

${ }^{99}$ See generally Social and Economic Rights Action Center v. Nigeria, African Commission on Human and Peoples' Rights, Case No. ACHPR/Comm/A044/1, Decision Regarding Comm. No. 155/96 (2001).
} 
one's physical environment. Accordingly, where environmental contamination and degradation pose a persistent threat to human life and health, the foregoing rights are implicated." 100

The right to family life is located in Article 8 of the European Convention on Human Rights, and has been interpreted to include a right to be free from pollution in one's home. ${ }^{101}$ The Universal Declaration of Human Rights similarly provides that " $[\mathrm{t}]$ he family is the natural and fundamental group unit of society and is entitled to protection by society and the State," and the International Covenant on Civil and Political Rights states that "[n]o one shall be subjected to arbitrary or unlawful interference with his privacy, family, [or] home."102 In López Ostra v. Spain, interpreting the European Convention on Human Rights, the European Court of Human Rights held that "severe environmental pollution may affect individuals' well-being and prevent them from enjoying their homes in such a way as to affect their private and family life adversely, without, however, seriously endangering their health." 103

While we did not identify any IMO documents citing the right to life or right to family life, they are among the bedrock human rights recognized in international law, and the IMO has made a firm commitment to defending human rights in general. ${ }^{104}$

National and multinational tribunals have specifically recognized that climate change can implicate the right to life and the right to family life. In Urgenda Foundation $v$. State of the Netherlands, the Supreme Court of the Netherlands concluded that the Dutch Government's GHG emissions target was so inadequate that it threatened both the right to life and the right to family life, reasoning that "there is the threat of dangerous climate change and it is clear that measures are urgently

100 Inter-Am.C.H.R., Report on the Situation of Human Rights in Ecuador, OEA/Serv.L./V/II.96, doc. 10 rev. 1 (1997).

${ }^{101}$ López Ostra v. Spain, Application No. 16798/90, Series A no. 303-C, (1995) 20 E.H.R.R. 277, Judgment of 9 December 1994 [hereinafter "López Ostra"].

102 International Covenant on Civil and Political Rights, art. 16(3).

103 See López Ostra, II 51.

${ }^{104}$ See, e.g., IMO, Message from Kitack Lim, Secretary-General, International Maritime Organization (Dec. 10, 2020), https://www.imo.org/en/MediaCentre/PressBriefings/pages/45Human-Rights-Day.aspx; OHCHR, UNHCR, IOM, UNODC and IMO Joint Statement on Protection at Sea in the Twenty-First Century (Dec. 10, 2014), https://www.ohchr.org/EN/ NewsEvents/Pages/DisplayNews.aspx?NewsID=15411\&LangID=E. 
needed." 105 The same year, the Administrative Court of Berlin concluded that Germany's climate policies must be consistent with the government's duty to protect fundamental rights provided by the German Constitution, including the right to life. ${ }^{106}$ In 2020 the UN Human Rights Committee found that climate change impacts - such as sea level rise-could become so severe as to violate the right to life. ${ }^{107}$

The right to life and the right to family life are therefore relevant to the IMO's authority to adopt an MBM in at least two ways. Protecting those rights requires emissions reductions consistent with the Paris Agreement temperature goals; and vindicating both rights requires allocating at least some of the revenue generated from an MBM to small-island nations whose survival is threatened by climate change.

\section{IMPACTS ON LDCS AND SIDS}

That any measures to address GHG emissions should not have a disproportionately adverse effect on least developed countries (LDC) and SIDs is a principle articulated in many multilateral environmental agreements. Principle 6 of the Rio Declaration, for example, notes that "[t]he special situation and needs of developing countries, particularly the least developed and those most environmentally vulnerable shall be given special priority." 108

A range of IMO instruments articulate the Organization's own commitment to considering the specific impacts any proposed GHG reduction measure will have on LDCs and SIDS. Most saliently, the IMO's Initial Strategy resolution states that "[t]he impacts on States of a measure should be assessed and taken into account as appropriate before adoption of the measure. Particular

105 HR. 20 Dec. 2019, NJ 19/00135 (Urgenda Foundation v. /State of the Netherlands, 19/00135 (Supreme Court of the Netherlands, 2019).) (Neth.) II 8.3.4.

106 Family Farmers and Greenpeace Germany v. Germany, 00271/17/R/SP (See [Admin. Ct. Berlin] 31 Oct. 2019)., VG 10 K 412.18 (Family Farmers/State of Germany) (Ger.).

107 See Human Rights Committee, Views adopted by the Committee under article 5 (4) of the Optional Protocol, CCPR/C/127/D/2728/2016.

No. 2728/2016; see also Hillary Aidun and \& Ama Francis, U.N. Human Rights Committee Issues Landmark Climate Migration Decision, SABIN CENTER FOR Climate CHANGE LAW CLIMATE LAW BLOG (Jan. 21, 2020).21, 2020), http://blogs.law.columbia.edu/climatechange/2020/01/21/landmark-u-ndecision-says-countries-may-not-turn-away-climate-migrants-in-the-future/.

${ }^{108}$ Rio Declaration, Principle 6. 
attention should be paid to the needs of developing countries, especially small island developing States and least developed countries." 109 Further, in its strategic plan the IMO committed to "ensure that the views of all stakeholders are taken into account in its decision-making processes and continue to pay particular attention to the needs of developing countries, especially small island developing States (SIDS) and least developed countries (LDCs)."110

In the context of GHG reduction measures, the IMO aims to address the needs of LDCs and SIDS by requiring an initial impact assessment to be submitted as part of any proposed measure. The MEPC has approved specific guidelines for how an impact assessment should be conducted: "simple, inclusive, transparent, flexible, evidence-based and measure-specific." 111 A key goal of this assessment is to ensure that if a specific GHG measure is adopted it will not disadvantage LDCs or SIDS relative to other member states and should ensure that the measure does not cause adverse economic impacts. ${ }^{112}$ Specifically, the assessments of a measure's impacts on LDCs and SIDS should consider:

\footnotetext{
${ }^{109}$ IMO Initial GHG Strategy, supra note 43 II 4.10 (explanatory parenthetical information omitted). ${ }^{110}$ Int'l Maritime Org. [IMO] A. 1110 (30), Six Year Strategic Plan for 2018-2023 II 3 (Dec. 8, 2017), https://wwwcdn.imo.org/localresources/en/KnowledgeCentre/IndexofIMOResolutions/AssemblyD ocuments/A.1110(30).pdf; see also Int'1 Maritime Org. [IMO] A. 1098 (29), High-Level Action Plan of the Organization and Priorities for the 2016-2017 Biennium Action 3.4.1, https://wwwcdn.imo.org/ localresources/en/KnowledgeCentre/IndexofIMOResolutions/AssemblyDocuments/A.1098(29).pdf ("Identify the emerging needs of developing States in general and the developmental needs of Small Island Developing States (SIDS) and Least Developed Countries (LDCs) in particular."). ${ }^{111}$ Marine Envtl. Prot. Comm. [MEPC], Procedure for Assessing Impacts on States of Candidate Measures, Doc. MEPC.1/Circ.885 (May 21, 2019), https://www.pmo.ir/fa/filepool2/download/ 3bffde5c75819b4bca7900200733e140d60eee51ae2e2c6db1f6b35e833c3aa2 [hereinafter Impact Assessment Procedure].

112 Harilaos N. Psaraftis \& Thalis Zis, Impact assessment of a mandatory operational goal-based short-term measure to reduce GHG emissions from ships: the LDC/SIDS case study, _ INT'L ENVTL. AGREEMENTS_ (2021), https://doi.org/10.1007/s10784-020-09523-2.
} 
(1) geographic remoteness of and connectivity to main markets; (2) cargo value and type; (3) transport dependency; (4) transport costs; (5) food security; (6) disaster response; (7) cost-effectiveness; and (8) socio-economic progress and development[.] $]^{113}$

IMO resolutions and multilateral treaties make it clear that any GHG measure that the IMO ultimately adopts must be one that does not place a disproportionate burden on LDCs and SIDS.

Although impact assessment may not provide an independent basis for the IMO to act, it will shape the type of measure the organization ultimately adopts. The results of impact assessment may provide an argument against an inappropriate greenhouse reduction measure, and one way to mitigate any disproportionately negative consequences a GHG reduction measure may have on SIDS and LDCs would be to transfer a portion of any proceeds from an MBM to those states in a way that would offset the costs a new measure imposes.

\section{NO MORE FAVORABLE TREATMENT}

Last, the "no more favorable treatment clause" requires parties to the various IMO conventions to apply those conventions to all ships that visit their ports, even if the visiting ship's flag state is not a party to the convention. The clause, also referred to as the "non-discrimination principle," appears in a range of IMO instruments including MARPOL ${ }^{114}$ and Resolution A.1119(30),

${ }^{113}$ Impact Assessment Procedure, supra note 111 II 8.2; see also, e.g., Marine Envtl. Prot. Comm. [MEPC], Detailed impact assessment of the mandatory operational goal-based short-term measure Submitted by Denmark, France and Germany, Doc. ISWG-GHG 7/2/20 (Feb. 7, 2020), https://shipowners.fi/wp-content/uploads/2020/02/ISWG-GHG-7-2-20-Detailed-impact-assessmentof-the-mandatory-operational-goal-based-short-term-measure-Denmark-France-and-Germa....pdf. ${ }^{114}$ MARPOL article 5(4) (“With respect to the ship of non-Parties to the Convention, Parties shall apply the requirements of the present Convention as may be necessary to ensure that no more favourable treatment is given to such ships."). 
which sets out procedures for port state control over the ships that visit them. ${ }^{115}$ In its Initial Strategy, the MEPC described the principle of non-discrimination and the principle of no more favorable treatment as guiding considerations for any greenhouse gas reductions measure. ${ }^{116}$

The clause exists to ensure that ships cannot gain an unfairly advantageous exemption from convention requirements by flying a non-signatory state's flag. ${ }^{117}$ Because IMO conventions allow port states to inspect and detain ships that do not comply with convention requirements, the clause should expand the overall effectiveness of an IMO measure. ${ }^{118}$ And from a point of view of a nonsignatory state it should not make any difference whether an IMO measure is imposed on it directly or through other states' enforcement at the other states' ports.

The clause does not provide an independent basis for the IMO to impose a greenhouse gas reduction measure, but instead ensures that any measure actually adopted will apply more broadly than to signatory states alone.

${ }^{115}$ Int'1 Maritime Org. [IMO], A. 1119 (30), Procedures for Port State Control, 2019 (Jan. 6, 2020), https://wwwcdn.imo.org/localresources/en/OurWork/IIIS/Documents/A\%2031-Res.1138\%20\%20PROCEDURES\%20FOR\%20PORT\%20STATE\%20CONTROL,\%202019.pdf; see also Convention on Standards of Training, Certification and Watchkeeping for Seafarers, 1978 article X(5), July 7, 1978, 1361 U.N.T.S. 2 ("This Article shall be applied as may be necessary to ensure that no more favourable treatment is given to ships entitled to fly the flag of a non-Party than is given to ships entitled to fly the flag of a Party."); International Convention for the Control and Management of Ships' Ballast Water and Sediments, June 5, 1992, 1760 U.N.T.S. 142 ("With respect to ships of nonParties to this Convention, Parties shall apply the requirements of this Convention as may be necessary to ensure that no more favourable treatment is given to such ships.").

116 See IMO Initial GHG Strategy, supra note 43 II 3.2.1.1.

117 See generally Katharina Reiling, The Emergence of Maritime Governance in the Post-War World, in SHIPPING AND GLOBALIZATION IN THE POST-WAR ERA (Niels P. Petersson et al., eds. 2019). 118 See Int'1 Maritime Org. [IMO], Submission by the International Maritime Organization to UNFCCC COP 15 II 16 (Dec. 7, 2009), https://unfccc.int/resource/docs/2009/smsn/igo/067.pdf ("IMO's most important conventions contain provisions to allow ships to be inspected through port State control, to ensure that they meet IMO requirements."). In the same position statement IMO noted that " $[\mathrm{t}]$ here is no precedent in any of the fifty-one IMO international treaty instruments currently in existence where measures are applied selectively to ships according to their flag ... [and] when IMO successfully dealt with [ozone depletion and transboundary pollution] at the request of the international community, the principle of a differentiated approach (according to flag) was not taken on board." Id. at II 25. 


\section{CONCLUSION}

In this paper we do not address whether IMO ought to act-and quickly-to address GHG emissions from shipping because there is no serious dispute that it must; the only open questions are around what exact measure the IMO will adopt and how it will justify that action. The polluter pays principle provides the strongest authority for the IMO to adopt a MBM on GHGs, as it is a clear foundation for the IMO to impose costs on shipping companies. Further, as noted throughout this paper, other principles guide the way in which a measure should be designed and applied and may provide general bases for the IMO to require GHG reductions from the shipping industry. These include the Paris Agreement's principle of highest ambition and principles established in international law that address transboundary pollution, intergenerational equity, and the right to life. Additionally, a number of principles weigh in favor of allocating at least some MBM revenue towards SIDs and other vulnerable nations. These include intergenerational equity and the right to life. 